\title{
UTILIZATION OF ANIMAL MEAL FOR GROWING OF WILLOW DEDICATED FOR ENERGY
}

\author{
Anna Nogalska', Andrzej Klasa', Małgorzata Skwierawska', Dorota Pilejczyk ${ }^{1}$ \\ 1 Department of Agricultural Chemistry and Environmental Protection, University of Warmia and Mazury in \\ Olsztyn, Oczapowskiego 8 Str., 10-718 Olsztyn, Poland, e-mail: anna.nogalska@uwm.edu.pl, andrzej.klasa@ \\ uwm.edu.pl, malgorzata.skwierawska@uwm.edu.pl, dorota.pilejczyk@uwm.edu.pl
}

Received: 2016.05 .18 Accepted: 2016.08.08 Published: 2016.09.20

\begin{abstract}
The aim of the study was to evaluate the effects of increased rates of meat and bone meal (MBM) to the soil on biomass yield, nitrogen $(\mathrm{N})$ and phosphorus $(\mathrm{P})$ content, and their accumulation in above ground biomass Salix viminalis, as well as the content of mineral $\mathrm{N}$ and available $\mathrm{P}$ forms in the soil. A two-year pot experiment was conducted at Warmia and Mazury University in Olsztyn (north-eastern Poland). Average biomass yield from two seasons of the studies was three higher from MBM treatments comparing to unfertilized control. Higher rates of MBM particularly in the second year showed higher yielding potential compared with mineral fertilizers. Willow biomass harvested from MBM treatments generally showed lower content of studied nutrients than willow from control treatment. It was found that in relation to the control accumulation of $\mathrm{N}$ in willow above ground biomass was significantly lower for $0.5 \% \mathrm{MBM}$ treatment and significantly higher for the treatment with the highest rate $(2.0 \%)$. The higher accumulation of $\mathrm{P}$ was found in the second year after MBM application, except treatment with the lowest MBM rate. Correlation coefficients values indicated that there is a relation between MBM rate and content of mineral $\mathrm{N}$ and available $\mathrm{P}$ in soil.
\end{abstract}

Keywords: willow coppice, soil, N, P, meat and bone meal (MBM).

\section{INTRODUCTION}

Worldwide demands for reliable renewable energy sources have been growing due to exhaustion of fossil fuels [Kauter et al. 2001, Szczukowski et al. 2001, Berndes et al. 2003, Bentsen and Felby 2012]. Biomass obtained from dedicated for energy willow coppice plantations is one of a quite promising renewable energy sources. Yield of willow biomass is determined by different factors and among them: weather conditions, genotype, density of planting and supply in water and nutrient seem to play predominant role. Application of optimal rates of fertilizers resulted in enhancing biomass yields but a wide range of biomass yields i.e. from 3 to $20 \mathrm{Mg} \mathrm{DM} \mathrm{ha}{ }^{-1}$ are reported. Mortensen et al. [1998] in three years studies showed a positive yield response of willow only in the first season of willow growth, whereas Quaye et al. [2011] did not find any effects of fertilization on willow biomass yield. Mineral fertilizers can be successfully replaced by organic wastes and among them sewage sludge and meat and bone meals can be taken into consideration. Dimitriou and Aronsson [2011] pointed out multibenefitial effects of utilization of organic wastes as soil amendments: return of biogenic substances, economical aspects and public acceptance.

Meat and bone meals are abundant in nitrogen (ca. $80 \mathrm{~kg} \mathrm{~N} \mathrm{Mg}^{-1}$ ) and phosphorus (ca. $50 \mathrm{~kg}$ $\mathrm{P} \mathrm{Mg}^{-1}$ ) and organic matter (ca. 70\%), therefore, their utilization as soil amendment seems to be a promising approach within strategy of sustainable development because it saves some environmental values [Mondini et al. 2008, Stępień and Szymczyk 2009]. There are many reports 
[Chaves et al. 2005, Jeng et al. 2006, Nogalska 2013, Nogalska and Zalewska 2013, Stępień and Wojtkowiak 2013] showing that soil application of MBM may be considered as a chance of considerable improving soil fertility. Application of animal meals in willow for energy plantations can be effective solution for utilization of difficult to manage organic wastes and low-cost production of energy from biomass.

It is known that due to its high demands willow coppice is able to utilize nutrients from wastes and other organic amendments but in available literature no report concerning application of MBM in willow plantations was found. Therefore, studies were undertaken to determine usability of MBM in willow for energy plantations.

\section{MATERIALS AND METHODS}

In a cold greenhouse owned by Warmia and Mazury University in Olsztyn in Poland twofactorial pot experiment was established and run in two seasons 2010 and 2011. Complete random design in four replications was used. The aim of the studies was to evaluate the effect of increasing rates of MBM on willow (Salix viminalis L.) cv. Turbo above ground biomass yield, content and accumulation of nutrients in obtained yield of aboveground biomass. Two $20 \mathrm{~cm}$ long willow cuttings were planted in $10 \mathrm{~kg}$ of soil medium in plastic pot of Kick-Brauckmann system. Soil was originated from loamy sand of slightly acidic reaction $\left(\mathrm{pH}_{(\mathrm{KCl})}=6.35\right)$ and showed the following content of available forms of $\mathrm{P}, \mathrm{K}$ and $\mathrm{Mg}$ : 64.5; 103.5 and $21.0 \mathrm{mg} \mathrm{kg}^{-1}$, respectively. The following six experimental treatments were compared: 0 (without fertilizers); NPK (mineral fertilizers control); 0.5\% MBM; 1.0\% MBM; 1.5\% MBM and $2.0 \% \mathrm{MBM}$ in relation to $10 \mathrm{~kg}$ of soil medium in each pot.

Meat and bone meal was applied once just before willow planting in 2010. MBM (this batch was classified as a material of low hazard) was produced in the plant owned by Saria company Poland it was located at Długi Borek close to Szczytno. The basic chemical composition of the studied MBM was as follows: dry matter 95.6\%; organic matter $71.4 \%$; crude ash $27.6 \%$; crude oil 136.9 g; 78.8 g N, 46.7 g P, 3.42 g K, 100.3 g Ca, $6.8 \mathrm{~g} \mathrm{Na}$ and $2.0 \mathrm{~g} \mathrm{Mg} \mathrm{kg}^{-1} \mathrm{DM}$. Because of low potassium content in MBM (ca. $3.5 \mathrm{~kg} \mathrm{~K} \mathrm{Mg}^{-1}$ ) rate of $1.25 \mathrm{~g} \mathrm{~K}$ just before planting was applied.
Control treatment (NPK) was fertilized only with mineral fertilizers: $\mathrm{N}-3.0 \mathrm{~g}$ (this rate was split just before planting and after willow establishing $-1.5 \mathrm{~g} \mathrm{~N}$, each) $\mathrm{P}-1.5 \mathrm{~g}$ and $\mathrm{K}-3.0 \mathrm{~g}$ this rate was split just before planting and after willow establishing $-1.5 \mathrm{~g} \mathrm{~K}$, each) applied per pot. Mineral fertilizers (NPK) and additional rate of $\mathrm{K}$ were applied also in the second season of the studies. Soil humidity in the pots was maintained at a level of $60 \%$ of the maximum water capacity.

After natural termination of willow growth above ground biomass was harvested from each pot and divided into stems and leaves. Then biomass was dried at $67^{\circ} \mathrm{C}$ and chemical analyses were performed. Samples of biomass were digested in $\mathrm{H}_{2} \mathrm{SO}_{4}$ with $\mathrm{H}_{2} \mathrm{O}_{2}$ as catalyzer. In the obtained digests content of the following nutrients was determined: total nitrogen by hypochloride method according to Baethen and Alley [1989], phosphorus by vanadium - molybdenum method [Panak 1997]. Accumulation of total nitrogen and phosphorus was calculated on the basis of nutrients content and biomass yields. After harvesting soil was sampled and the content of available forms of nitrogen and phosphorus was determined. Mineral nitrogen forms were determined just after sampling after extraction with $1 \%$ solution of $\mathrm{K}_{2} \mathrm{SO}_{4}$ and in extracts $\mathrm{N}^{-} \mathrm{NH}_{4}^{+}$with Nessler's reagent and $\mathrm{N}^{-\mathrm{NO}_{3}}{ }^{-}$with phenodisulphic acid, available phosphorus by Egner-Riem's [Panak 1997].

Results obtained from chemical analysis of willow biomass were subjected to ANOVA (STATISTICA 10 software) for two factorial experiment a in completely randomized design assuming that factor $\mathrm{a}$ - was a rate of MBM; factor $\mathrm{b}$ - was a season of studies at the level. The significance of differences between arithmetic means was estimated by Tukey's test $(P \leq 0.01)$. To estimate the environmental effects of MBM incorporation into soil the coefficients of Pearson's correlation between the rate of MBM and concentrations of mineral nitrogen and available phosphorus in soil were calculated.

\section{RESULTS AND DISCUSSION}

Turbo cultivar of willow was registered by Department of Plant Breeding and Seed Production of Warmia and Mazury University in Olsztyn. This cultivar is characterized by lanceolate leaves, long stems and short branches. It is a universal form which appeared to be relatively high 
resistant to diseases and pests of high yielding potential of biomass for energy. Under conditions of pot trial three-fold higher yield of biomass (average values for two seasons) was registered from MBM treatments compared to control (Table 1). Yields of leaves biomass were within the range from 8.68 (without fertilizers) to $32.39 \mathrm{~g} \mathrm{DM} \mathrm{pot}^{-1}$ (for treatment with the highest MBM rate i.e. 2.0\%). Comparing to yield obtained in control treatment (NPK) application the lowest MBM rate $(0.5 \%)$ resulted in significant reduction (ca. 16\%) of leaves yield. It was caused by complete exhaustion of nutrients in the course of the experiment because high yield of leaves from this treatment was recorded $\left(34.20 \mathrm{~g} \mathrm{DM} \mathrm{pot}^{-1}\right)$ in the first season as well as high yield of stems biomass (63.60 g DM pot $\left.{ }^{-1}\right)$. Contrary results were noted i.e. enhancing leaves biomass yields under effect of increased rates of MBM in the second season of studies comparing to the first one. In three treatments with MBM application $(0.5 ; 1.0$ and $2.0 \%)$ significant increase of stem biomass was found - in average $23 \%$. Differences of stem biomass yields obtained in the first and the second season of studies appeared to be statistically proven. It was related to the increase of stem yield (by 1.7fold) noted for the treatment with 0.5\% MBM. Kalembasa et al. [2006], Klasa et al. [2008] and Nowak et al. [2012] in the result of application sewage sludge or compost reported high biomass yield of stems. Yield bearing effects of MBM soil application was noted by many authors [Jeng et al. 2004, 2006, Chaves et al. 2005, Ylivainio et al. 2008, Nogalska et al. 2013, Nogalska et al. 2014].
The content of nitrogen in leaves ranged from 23.01 to $46.95 \mathrm{~g} \mathrm{~N} \mathrm{~kg}^{-1}$ (Table 2). With increasing rate of MBM nitrogen concentration in leaves and stem also increased. In comparison to the control, higher rates of MBM (1.0; 1.5 and $2.0 \%)$ resulted in significant increase of $\mathrm{N}$ concentration in willow leaves whereas for the lowest applied MBM rate $(0.5 \%)$ statistically proven reduction of $\mathrm{N}$ concentration was found. Therefore, it can be concluded that this rate of MBM did not cover $\mathrm{N}$ demands of willow. Leaves collected in the first season of studies (2010) showed higher $\mathrm{N}$ content that in the second (relatively by $21 \%$ ) and contrary was found in the case of $\mathrm{N}$ content in willow stems. Concentration of $\mathrm{N}$ in stems was lower (by about 3-fold) that in leaves ranging from 6.63 to $18.71 \mathrm{~g} \cdot \mathrm{N} \mathrm{kg}^{-1}$. Meat and bone meal soil application resulted in reduction of $\mathrm{N}$ content in stems to $35 \%$ in relation to control. Kalembasa et al. [2006] found no modification of $\mathrm{N}$ content in willow shoots under conditions of soil application of sewage sludge and it was relatively constant i.e. between 7.40 and $7.50 \mathrm{~g} \mathrm{~N} \mathrm{~kg}^{-1}$. Also nitrogen fertilization had no effect on the nitrogen content in wood of willow [Mortensen et al. 1998].

Content of $\mathrm{P}$ in leaves of willow found for treatments with MBM application was close to respective values for control plants (Table 2). Our earlier studies [Nogalska and Zalewska 2013] with others crops supported this results. Variability of phosphorus content in willow leaves ranged from 1.08 to $1.92 \mathrm{~g} \mathrm{P} \mathrm{kg}^{-1} \mathrm{DM}$. The content of phosphorus in stem biomass (similarly to nitrogen) was significantly lower for treatments with MBM application comparing o NPK treat-

Table 1. Yield of above ground willow biomass in relations to increasing rates of meat and bone meal (MBM) $\left(\mathrm{g} \operatorname{pot}^{-1} \mathrm{DM}\right)$

\begin{tabular}{|c|c|c|c|c|c|c|}
\hline \multirow[b]{2}{*}{ Treatment } & \multicolumn{3}{|c|}{ Leaves } & \multicolumn{3}{|c|}{ Stems } \\
\hline & 2010 & 2011 & $\begin{array}{c}\text { mean for } \\
\text { dose }\end{array}$ & 2010 & 2011 & $\begin{array}{c}\text { mean for } \\
\text { dose }\end{array}$ \\
\hline 0 & 10.56 & 6.80 & $8.68 a$ & 15.81 & 7.72 & $11.76 a$ \\
\hline Control NPK & 27.61 & 32.64 & $30.12 c$ & 34.12 & 35.24 & $34.68 b$ \\
\hline $0.5 \% \mathrm{MBM}+\mathrm{K}$ & 34.20 & 16.52 & $25.36 b$ & 63.60 & 28.76 & $46.18 d$ \\
\hline $1.0 \% \mathrm{MBM}+\mathrm{K}$ & 27.16 & 37.48 & $32.32 \mathrm{c}$ & 37.85 & 41.92 & $39.88 c$ \\
\hline $1.5 \% \mathrm{MBM}+\mathrm{K}$ & 29.38 & 33.05 & $31.21 \mathrm{c}$ & 33.93 & 34.68 & $34.30 \mathrm{~b}$ \\
\hline $2.0 \% \mathrm{MBM}+\mathrm{K}$ & 31.06 & 33.73 & $32.39 c$ & 42.69 & 37.86 & $40.27 c$ \\
\hline Mean for year & 26.66 & 26.70 & & $38.00 \mathrm{~b}$ & $31.03 a$ & \\
\hline
\end{tabular}

$0-$ without fertilizers.

NPK - mineral fertilizers.

$\mathrm{MBM}+\mathrm{K}-$ meat and bone meal applied with $\mathrm{K}$ mineral fertilizers as in NPK.

Values associated with the same letter are not significantly different according to Tukey's test $(P \leq 0.01)$. 
Table 2. Effect of MBM soil application on content of nitrogen $(\mathrm{N})$ and phosphorus $(\mathrm{P})$ in leaves and stems of willow and accumulation of these macronutrients in shoots of willow (stem + leaves)

\begin{tabular}{|c|c|c|c|c|c|c|c|c|c|}
\hline \multirow{4}{*}{ Treatment } & \multicolumn{9}{|c|}{ Nitrogen } \\
\hline & \multicolumn{6}{|c|}{ content ( $\left.\mathrm{g} \mathrm{kg}^{-1} \mathrm{DM}\right)$} & \multicolumn{3}{|c|}{ uptake $\left(\mathrm{mg} \mathrm{pot}^{-1}\right)$} \\
\hline & \multicolumn{2}{|c|}{ leaves } & \multirow{2}{*}{$\begin{array}{l}\text { mean for } \\
\text { dose }\end{array}$} & \multicolumn{2}{|c|}{ stems } & \multirow{2}{*}{$\begin{array}{c}\text { mean for } \\
\text { dose }\end{array}$} & \multirow{2}{*}{2010} & \multirow{2}{*}{2011} & \multirow{2}{*}{$\begin{array}{c}\text { mean for } \\
\text { dose }\end{array}$} \\
\hline & 2010 & 2011 & & 2010 & 2011 & & & & \\
\hline 0 & 17.29 & 28.73 & $23.01 a$ & 3.42 & 9.85 & $6.63 a$ & 236 & 273 & $254 a$ \\
\hline Control NPK & 34.31 & 36.89 & $35.60 \mathrm{c}$ & 14.46 & 22.96 & $18.71 \mathrm{f}$ & 1443 & 2018 & $1730 c$ \\
\hline $0.5 \% \mathrm{MBM}+\mathrm{K}$ & 28.15 & 23.39 & $25.77 b$ & 6.49 & 10.85 & $8.67 b$ & 1381 & 695 & $1038 b$ \\
\hline $1.0 \% \mathrm{MBM}+\mathrm{K}$ & 50.23 & 38.48 & $44.35 d$ & 8.96 & 11.23 & $10.09 \mathrm{c}$ & 1697 & 1911 & $1804 c$ \\
\hline $1.5 \% \mathrm{MBM}+\mathrm{K}$ & 55.29 & 37.09 & $46.19 \mathrm{e}$ & 10.83 & 17.88 & $14.35 d$ & 2005 & 1853 & $1929 \mathrm{~cd}$ \\
\hline $2.0 \% \mathrm{MBM}+\mathrm{K}$ & 58.07 & 35.83 & $46.95 \mathrm{e}$ & 10.59 & 19.87 & $15.23 e$ & 2264 & 1979 & $2121 d$ \\
\hline Mean for year & $40.55 b$ & $33.40 a$ & - & $9.12 a$ & $15.44 b$ & - & 1504 & 1455 & - \\
\hline \multicolumn{10}{|c|}{ Phosphorus } \\
\hline 0 & 1.06 & 1.10 & $1.08 a$ & 1.49 & 1.65 & $1.57 a b$ & 35 & 20 & $27 a$ \\
\hline Control NPK & 2.22 & 1.63 & $1.92 b$ & 2.25 & 1.64 & $1.94 d$ & 138 & 111 & $124 \mathrm{c}$ \\
\hline $0.5 \% \mathrm{MBM}+\mathrm{K}$ & 1.72 & 1.84 & $1.78 b$ & 1.37 & 1.47 & $1.42 a$ & 146 & 72 & $109 b$ \\
\hline $1.0 \% \mathrm{MBM}+\mathrm{K}$ & 1.65 & 2.12 & $1.88 \mathrm{~b}$ & 1.74 & 1.37 & $1.55 a b$ & 110 & 137 & $123 c$ \\
\hline $1.5 \% \mathrm{MBM}+\mathrm{K}$ & 1.85 & 1.87 & $1.86 \mathrm{~b}$ & 1.60 & 1.75 & $1.67 \mathrm{bc}$ & 108 & 122 & $115 \mathrm{c}$ \\
\hline $2.0 \% \mathrm{MBM}+\mathrm{K}$ & 1.51 & 1.86 & $1.68 b$ & 1.61 & 1.43 & $1.52 \mathrm{ac}$ & 115 & 116 & $115 c$ \\
\hline Mean for year & 1.67 & 1.74 & - & $1.67 \mathrm{~b}$ & $1.55 a$ & - & $109 b$ & $96 a$ & - \\
\hline
\end{tabular}

ment. Willow stems harvested in the first season of the studies showed higher P content than in the second season and this difference was statistically proven. Analyzing content of this nutrient in leaves tissues no differences between seasons were found. Nowak et al. [2012] noted similar content of $\mathrm{P}$ in willow tissues comparing to reported herein. However, Ylivainio et al. [2008] reported increase of $\mathrm{P}$ concentration in plant tissues under effect of MBM soil application.

In the first season of the studies accumulation of nitrogen in the above ground biomass enhanced along with increase of MBM rate to the soil while the highest amount of this nutrient was accumulated in willow tissues at treatment of $2.0 \% \mathrm{MBM}$ (on an average more by $57 \%$ comparing to NPK treatment) (Table 2). In the next season of studies values of nitrogen accumulation in willow biomass were less variable than in the first season and only in case of treatment $0.5 \% \mathrm{MBM}$ distinctive lower $\mathrm{N}$ accumulation was noted, what reflected lower biomass yield as well as relative low nitrogen content in above ground biomass. Taking into account mean values from two seasons it was found the significant reduction of nitrogen accumulation for treatment with the lowest MBM $(0.5 \%$ MBM) and the significant increase of this parameter for the highest MBM rate $(2.0 \%$
MBM). Higher accumulation of phosphorus in willow biomass was found in the first season of the studies only for the treatment with the lowest MBM soil rate. The other MBM rates better supplied willow in phosphorus in the second season of the studies. It indicated low rate of mobilization of this nutrient from applied meat and bone meal which was abundant in phosphorus.

Nitrogen which is the most yield bearing nutrient, on the other hand, posses a serious threat to water environment. Particularly nitrogen mineral forms are considered as the most hazardous. Meat and bone meals contain nitrogen in protein form which has to undergo mineralization process and in the first year is available for plants [Chaves et al. 2005, Jeng et al. 2004, 2006].

In the treatment with $1.0 \%$ of MBM the total nitrogen rate amounted to $8.0 \mathrm{~g} \mathrm{~N}$ pot $^{-1}$ and in treatment with NPK $6.0 \mathrm{~g} \mathrm{~N}^{\text {pot }}{ }^{-1}$. MBM was applied once during the course of the $r$ studies and NPK four times (twice in each growing season 1.5 g pot-1 each time). Regression analysis has shown that there is a significant relation between MBM rate and content of $\mathrm{N}_{\min }$. in the soil ( $\left.\mathrm{r}=0.81\right)$ (Figure 2) and $\mathrm{N}^{-\mathrm{NO}_{3}}{ }^{-}(\mathrm{r}=0.72)$ (Figure 1). It has to be stressed that it was fund for soil sampled after first growing season (November 2011). According to Szczukowski et al. [2001] the high fertiliz- 
ers rates should be applied in the second growing season. It was assumed that MBM can act as slow releasing fertilizer for willow. High values of correlation coefficients (Figure 1) confirm opinion expressed by Jeng and Vagstadt [2009] that application of MBM in too high rates can posses a potential biohazards. Harvesting of willow biomass after the first growing season stimulate branching what in the field conditions leads to canopy closing and limitation of weeds development and reducing of nutrients losses from the soil. It was found that higher MBM rates resulted increase in the second season but the difference between treatments with 1.0 and $2.0 \%$ of MBM was not significant (Table 1). What was stated it was significant increase of nitrates in soil (by the factor of 3.8) (Figure 1). It can be explained by the fact that mineralization process of MBM takes a long time what was reported by SpychajFabisiak et al. [2007] and Nogalska [2013]. Jeng et al. [2004, 2006] found that in the first year as much as $80 \%$ of nitrogen from MBM is released what is in accordance with Mondini et al. [2008] report where is stated that the rate of MBM mineralization in the soil is fast and that this waste cannot be applied in high rates. Therefore proper i.e. balanced rates of MBM for perennial crops should be calculated.

The rate of $1.0 \%$ of $\mathrm{MBM}$ corresponded to $5.0 \mathrm{~g}$ P (once for two years) whereas mineral fer-

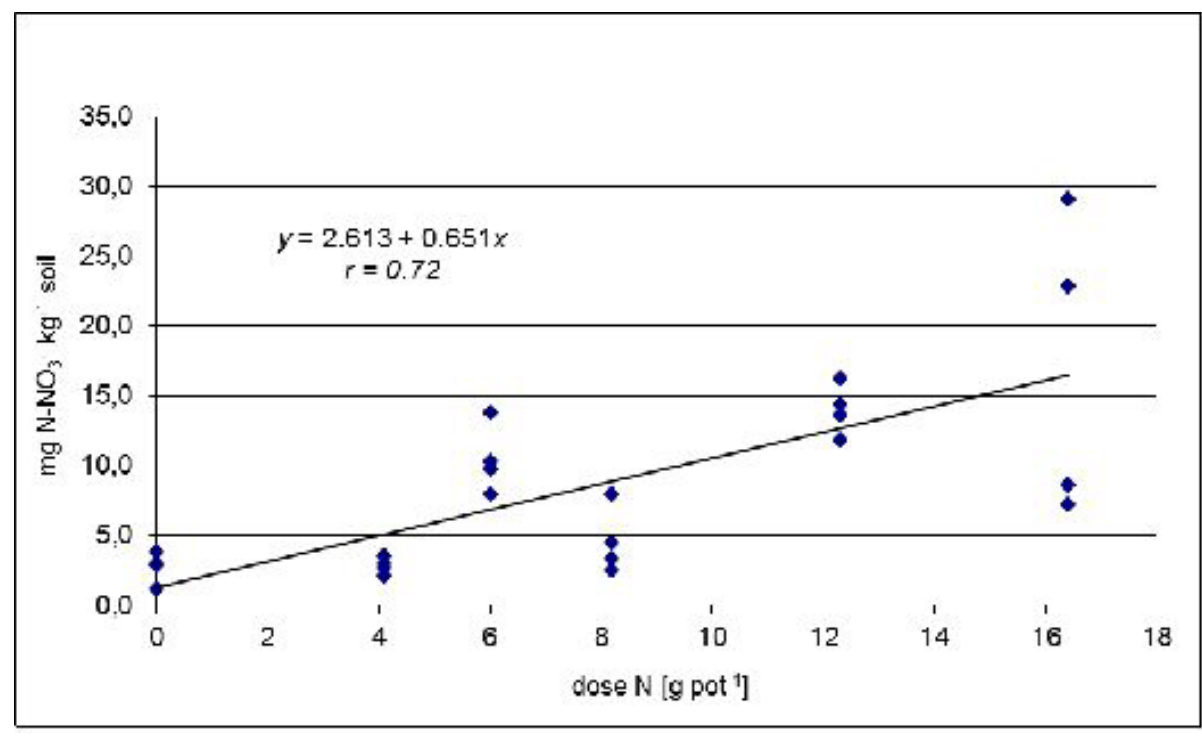

Figure 1. Relationships between the quantity of applied $\mathrm{N}$ during the experiment and content of $\mathrm{N}^{-N_{3}}$ /in soil $(\mathrm{r}=0.72)$

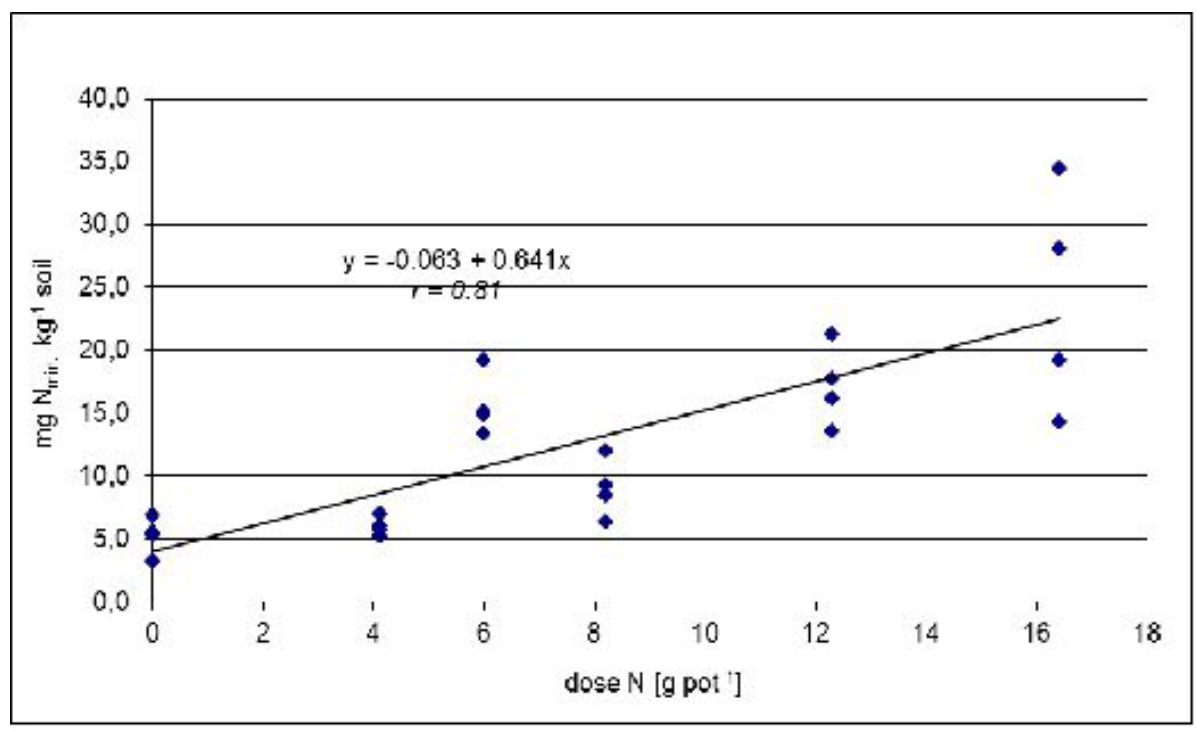

Figure 2. Relationships between the quantity of applied $\mathrm{N}$ during the experiment and content of $\mathrm{N}_{\min }$ in soil $(\mathrm{r}=0.81)$ 


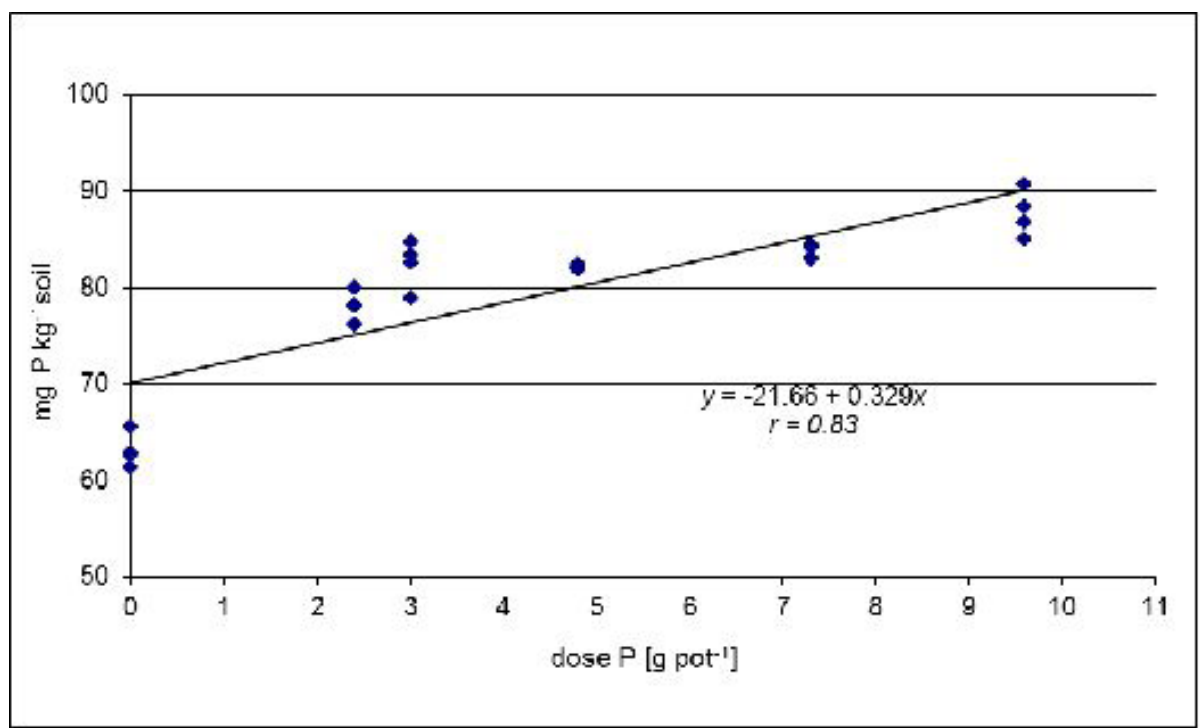

Figure 3. Relationships between the quantity of applied phosphorus $(\mathrm{P})$ during the experiment and content of $\mathrm{P}$ available in soil $(\mathrm{r}=0.83)$

tilizers were applied at the rate of $3.0 \mathrm{~g} \mathrm{P}^{-1}$ (1.5 g P annually). Very high value of correlation coefficient $(\mathrm{r}=0.83)$ indicated positive relation between MBM rate and content of available phosphorus in soil (Figure 3). However, an increase of MBM rate (from 1 to $2 \%$ ) resulted only in 7\% enhancement of amount of available phosphorus in soil what clearly indicate that this nutrient does not posses any threat to water environment. It should be mentioned that phosphorus in MBM occurs in organic form (meat fraction) which is easily mineralized and as apatite (bone fraction) which is mobile only under low $\mathrm{pH}$ conditions [Jeng et al. 2006, Ylivainio et al. 2008]. Some authors expressed opinion that phosphorus released in the first year can absorbed by plant root systems in the next growing seasons [Valenzuela et al. 2001, Jeng et al. 2006, Arvanitoyannis and Ladas 2008].

\section{CONCLUSIONS}

From the results of performed studies it can be concluded that MBM applied to soil in increased rates affected biomass yield of willow. Obtained yields for treatments with MBM was three times higher comparing to unfertilized control. Higher rates of MBM applied to the soil showed higher yielding potential in the second season after application than mineral fertilizers. Content of $\mathrm{N}$ and $\mathrm{P}$ in willow leaves and stems was related to MBM rate and season of the studies. Willow grown on medium with MBM generally showed lower concentration of studied nutrients than control (NPK). The significant reduction of nitrogen accumulation in biomass and significant increase for treatment with lowest and highest applied MBM rate $(0.5$ and $2.0 \%)$, respectively. Higher accumulation of phosphorus by willow was found in the first growing season only for treatment with the lowest MBM rate. The other studied MBM rates better supplied willow in phosphorus in the second season of the studies. High values of correlation coefficients show that there is a relation between MBM rate and available $\mathrm{P}$ as well as mineral $\mathrm{N}$ content in the soil (especially in nitrate form). From our results it can be concluded that the rate of $1.0 \%$ MBM applied to the soil cannot be exceeded because of environmental hazards possessed by higher MBM rates. This report is based on the results obtained in two seasons' pot experiment and results have to be confirmed under open field conditions.

\section{Acknowledgements}

Supported by the Ministry of Science and Higher Education of Poland, Project No. 20.610.002-300.

\section{REFERENCES}

1. Arvanitoyannis I.S., Ladas D. 2008. Meat waste treatment methods and potential uses. International Journal of Food Science and Technology, 43, 543-559. 
2. Baethen W.R., Alley M.M. 1989. A manual colorimetric procedure for measuring ammonium nitrogen in soil and plant Kjeldahl digests. Communications in Soil Science and Plant Analysis, 20, 961-969.

3. Bentsen N.S., Felby C. 2012. Biomass for energy in the European Union a review of bioenergy resource assessments. Biotechnology for Biofuels, 5(1), 25.

4. Berndes G.M., Hoogwijk R., van den Broek R. 2003. The contribution of biomass in the future global energy supply: a review of 17 studies. Biomass Bioenergy 25(1), 1-28.

5. Chaves C., Canet R., Albiach R., Marin J., Pomares F. 2005. Meat and bone meal: fertilizing values and rates of nitrogen mineralization. Nutrient and Carbon Cycling in Sustainable Plant-Soil Systems, 1(6-9), 177-180.

6. Dimitriou I., Aronsson P. 2011. Wastewater and sewage sludge application to willows and poplars grown in lysimeters-plant response and treatment efficiency. Biomass Bioenergy, 35(1), 161-170.

7. Jeng A., Haraldsen T.K., Vagstad N., Grønlund A. 2004. Meat and bone meal as nitro gen fertilizer to cereals is Norway. Agricultural and Food Science, 13, 268-275.

8. Jeng A.S., Haraldsen T.K., Grønlund A., Pedersen P.A. 2006. Meat and bone meal as nitrogen and phosphorus fertilizer to cereals and rye grass. $\mathrm{Nu}$ trient Cycling in Agroecosystems, 76, 183-191.

9. Jeng A.S., Vagstad N. 2009. Potential nitrogen and phosphorus leaching from soils fertilized with meat and bone meal. Acta Agriculturae Scandinavica, Section B-Soil \& Plant Science, 59(3), 238-245.

10. Kalembasa D., Szczukowski S., Cichuta R., Wysokiński A. 2006. The yield of biomass and content of nitrogen in willow (Salix viminalis) at different nitrogen fertilization rate. Pamiętnik Puławski, 142, 171-178.

11. Kauter D., Lewandowski I., Claupein W. 2001. Pappeln in Kurzumtriebswirtschaft: Eigenschaften und Qualitätsmanagement bei der Festbrennstoffbereitstellung-Ein Überblick. Pflanzenbauwissenschaften, 5, 64-74.

12. Klasa A., Księżniak A., Szałański W. 2008. Estimation of the effects of mycorrhizal fungi application of yield and chemical composition of above ground biomass of short rotation willow. Pamiętnik Puławski, 148, 25-36.

13. Mondini C., Cayuela M.L., Sinicco T., SanchezMonedero M.A., Bertolone E., Bardi L. 2008. Soil application of meat and bone meal. Short-term effects on mineralization dynamics and soil biochemical and microbiological properties. Soil Biology \& Biochemistry, 40, 462-474.

14. Mortensen J., Nielsen K.H., Jorgensen U. 1998. Nitrate leaching during establishment of willow (Salix viminalis) on two soil types and at two fertil- ization levels. Biomass Bioenergy, 15(6), 457-466.

15. Nogalska A. 2013. Changes in the soil nitrogen content caused by direct and residual effect of meat and bone meal. Journal of Elementology, 18(4), 659-671.

16. Nogalska A., Chen L., Sienkiewicz S., Nogalski Z. 2014. Meat and bone meal as nitrogen and phosphorus supplier to cereals and oilseed rape. Agricultural and Food Science, 23(1), 19-27.

17. Nogalska A., Skwierawska M., Nogalski Z., Kaszuba M. 2013. The effect of increasing doses of meat and bone meal (MBM) applied every second year on maize grown for grain. Chilean Journal of Agricultural Research, 73(4), 430-434.

18. Nogalska A., Zalewska M. 2013. The effect of meat and bone meal on phosphorus concentrations in soil and crop plants. Plant, Soil and Environment, 59(12), 575-580.

19. Nowak D., Jasiewicz Cz., Kwaśniewski D. 2012. Influence of mineral fertilizer and compost on yield and chemical composition of willow. Inżynieria Rolnicza, 4(139), 295-301.

20. Panak H. 1997. Metodical Guide to Agricultural Chemistry. Wydawnictwo ART, Olsztyn.

21. Quaye A.K., Volk T.A., Hafner S., Leopold D.J., Schirmer C. 2011. Impacts of paper sludge and manure on soil and biomass production of willow. Biomass Bioenergy, 35(7), 2796-2806.

22. Spychaj-Fabisiak E., Kozera W., Majcherczak E., Ralcewicz M., Knapkowski T. 2007. Evaluation of light soil fertility after the application of organic waste and manure. Acta Scientiarum Polonorum, Agricultura, 6(3), 69-76.

23. Stępień A., Szymczyk S. 2009. Application of meat and bone meals in agricultural ecosystems and their effect on the aquatic environment. Ecosystems and Sustainable Development VII. WIT Transactions on Ecology and the Environment, 122, 449-457.

24. Stępień A., Wojtkowiak K. 2013. Composition of gluten proteins in spring and winter wheat grain cultivated under conditions of varied fertilization. Acta Agriculturae Scandinavica, Section B - Soil \& Plant Science, 63(7), 588-594.

25. Szczukowski S., Tworkowski J., Stolarski M., Sobotka W. 2001. Biomass from short rotation willow plantations as a source of environmentally friendly fuel. Zeszyty Problemowe Postępów Nauk Rolniczych, 477, 187-193.

26. Ylivainio K, Uusitalo R, Turtola E. 2008. Meat bone meal and fox manure as $\mathrm{P}$ sources for ryegrass (Lolium multiflorum) grown on a limed soil. Nutrient Cycling in Agroecosystems, 81, 267-278.

27. Valenzuela H.R., Goo T., Randall H., Hamasaki R.H., Radovich T. 2000. The effect of bone meal on the yield of jicama. Pachyrhizus Erosus in Oahu Hawaii. Proceedings of the Florida State Hortticultural Society, 113, 222-226. 